\title{
New records of Orchidaceae Juss. for the state from Hidalgo, Mexico
}

\author{
Carlos Alberto Hernández-Orta ${ }^{1}$, Karla María Aguilar-Dorantes², Jonas Morales-Linares ${ }^{2}$, \\ Vincenzo Bertolini ${ }^{3}$
}

\begin{abstract}
1 Facultad de Ciencias Biológicas, Universidad Autónoma del Estado de Morelos, Avenida Universidad 1001, Col. Chamilpa, Cuernavaca, Morelos, C.P. 62209 México. 2 Centro de Investigación en Biodiversidad y Conservación, Universidad Autónoma del Estado de Morelos, Avenida Universidad 1001, Col. Chamilpa, Cuernavaca, Morelos, C.P. 62209, México. 3 El Colegio de la Frontera Sur (ECOSUR), Km 2.5 Carretera Aeropuerto Antiguo, Tapachula, Chiapas, C.P. 30700, México.

Corresponding author: Karla María Aguilar-Dorantes, karla.aguilar@uaem.mx
\end{abstract}

\begin{abstract}
Two new orchid records are reported for Hidalgo, Notylia barkeri Lindl. and Trichocentrum cosymbephorum (C. Morren) R. Jiménez \& Carnevali. The genus Notylia is reported for the first time, and the list of orchid flora is updated to include 110 taxa. Unexpectedly, the species were recorded in abandoned orange plantations rather than natural vegetation, likely because of the high anthropogenic pressure exerted on their natural populations. These new records highlight the importance of continuing to survey regions such as Hidalgo with scarce orchid records, including both natural and modified vegetation.
\end{abstract}

\section{Keywords}

Abandoned orange crops, Hidalgo Huasteca, orchid flora, semi-evergreen tropical forest.

Academic editor: Alexander Zizka | Received 10 May 2019 | Accepted 30 August 2019 | Published 27 September 2019

Citation: Hernández-Orta CA, Aguilar-Dorantes KM, Morales-Linares J, Bertolini V (2019) New records of Orchidaceae Juss. for the state from Hidalgo, Mexico. Check List 15 (5): 827-832. https://doi.org/10.15560/15.5.827

\section{Introduction}

The family Orchidaceae Juss. has a worldwide distribution and is characterized by for its highly diverse morphology and species richness. The family is represented by approximately 27,801 species (The Plant List 2018; Givnish et al. 2016). In Mexico, 168 genera and around 1,250 species have been recorded, of which 444 species are endemic (Soto-Arenas 1996; Hágsater et al. 2005; Soto-Arenas et al. 2007). In the state of Hidalgo, 108 orchid taxa had been recorded, which represent around $8 \%$ of the orchid flora at the national level (Ponce-Vargas et al. 2006; Ceja-Romero et al. 2010; Bertolini et al. 2012, 2016; Molina-Mendoza et al. 2012).
Semi-evergreen tropical forest in Mexico is found along the coast of the Gulf of Mexico (Challenger 1988). In particular, the Huasteca region, which extends across the states of Hidalgo, San Luis Potosí, and Veracruz, has the northernmost extent of semi-evergreen tropical forest on the American continent (Luna 1997). In Hidalgo, semi-evergreen tropical forest has been severely fragmented and transformed to crops. Seven species of orchid have been reported in semi-evergreen tropical forest in Hidalgo (Ceja-Romero et al. 2010; Bertolini et al. 2012). In the municipality of San Felipe Orizatlán, in the Huasteca of Hidalgo, there are several important fragments of semi-evergreen tropical forest mixed 
with abandoned orange plantations, yet this municipality has been little explored for orchids. Only four species of orchid have been reported until now: Bletia coccinea Lex., Vanilla planifolia Jacks. ex Andrews, Prosthechea radiata (Lindl.) W.E. Higgins, and Oncidium sphacelatum Lindl. We carried out botanical surveys in the municipality of San Felipe Orizatlán in a semi-evergreen tropical forest and abandoned orange plantations and expand the knowledge of the orchid flora in the state of Hidalgo as a result of these surveys.

\section{Methods}

In March 2017, three botanical surveys were carried out in $4 \mathrm{~km}$ each of semi-evergreen tropical forest fragments and abandoned orange plantations in Ahuatitla, municipality of San Felipe Orizatlán (2109' N, 098³9’ W), in the Huasteca of Hidalgo (Fig. 1). Each of these surveys had a duration of approximately 4.5 hours. Two local guides and a botanical expert (Ricardo Alejandro Garza Paredes) aided us in determining our plots. In April the three established plots of 1 ha were studied by two researchers, about two hours each, to detect the presence of flowers in Notylia barkeri Lindl. and Trichocentrum cosymbephorum (C. Morren) R. Jiménez \& Carnevali. As no flowers were detected in T. cosymbephorum, a second visit was conducted during of October and a third visit of November.
The literature recording orchids in the state of Hidalgo was reviewed (Villavicencio-Nieto et al. 1998; Ponce-Vargas et al. 2006; Ceja-Romero et al. 2010; Bertolini et al. 2012, 2016; Molina-Mendoza et al. 2012), The collected specimens were identified by specialists and were herborized following the techniques of Lot and Chiang (1986). The species names were verified according to The Plant List (2018). The identity and geographic distribution of the specimens were additionally corroborated with specimens from the National Herbarium of the National Autonomous University of Mexico (MEXU), the Metropolitan Autonomous University (UAMIZ), and the herbarium of the Center for Biological Studies of the Institute of Basic Sciences and Engineering of the Autonomous University of Hidalgo (HGOM), as well as with specimens in online databases such as Tropicos, The Plant List, and the Global Biodiversity Information Facility (GBIF). Finally, the collected specimens were deposited in the herbarium of the Center for Biodiversity and Conservation Research of the Autonomous University of the State of Mexico (HUMO).

\section{Results}

Two new records of orchids are added to the flora of Hidalgo (Ponce-Vargas et al. 2006; Ceja-Romero et al. 2010; Bertolini et al. 2012, 2016, Molina-Mendoza et al. 2012).

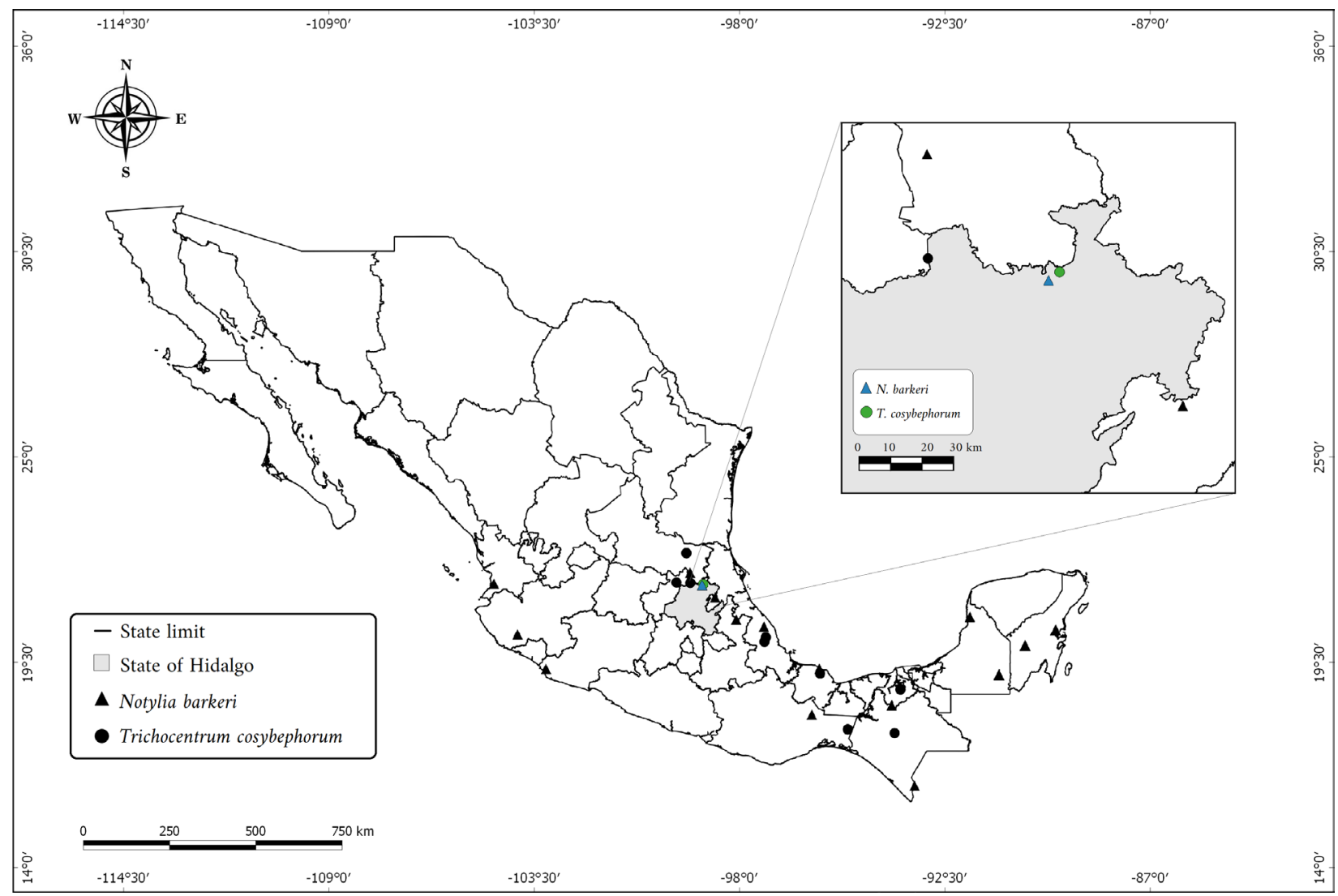

Figure 1. Notylia barkeri Lindl. geographic distribution map with data from herbaria and GBIF records (see Table 1), and Trichocentrum cosymbephorum (C. Morren) R. Jiménez \& Carnevali in Mexico. The new records contributed by this study are highlighted with color. 


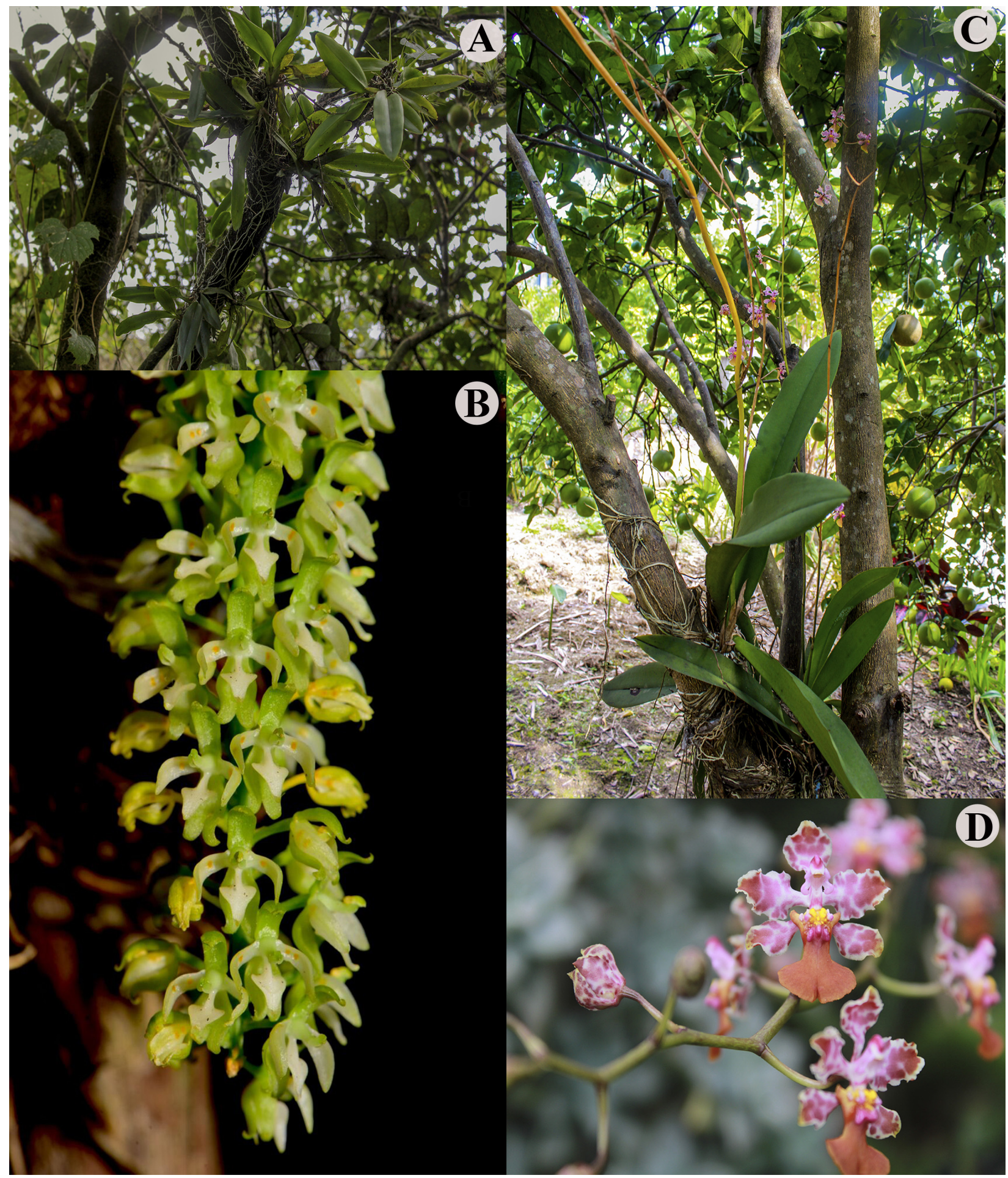

Figure 2. A, B. Notylia barkeri Lindl. C, D. Trichocentrum cosymbephorum (C. Morren) R. Jiménez \& Carnevali. A, C. Habit. B, D. Flowers.

\section{Notylia barkeri Lindl.}

New record. Mexico: Hidalgo: municipality of San Felipe Orizatlán, Ahuatitla $\left(21^{\circ} 08^{\prime} 33.60^{\prime \prime} \mathrm{N}, 098^{\circ} 40^{\prime} 27.80^{\prime \prime} \mathrm{W}\right.$, $364 \mathrm{~m}$ elev.), in abandoned orange (Citrus spp.) plantation "Atotomoc", coll. by A. Hernández-Orta, 11 April 2017, (HUMO) (Fig. 2A, B).

Identification. Notylia barkeri is a small epiphyte, often with long, pendent roots; pseudobulbs oblong, to 2.5 $\mathrm{cm}$ long and $1 \mathrm{~cm}$ wide, enveloped at base by several imbricating bracts. Leaves solitary from apex of pseudobulb, ligulate, $8-18 \mathrm{~cm}$ long, $1.3-4 \mathrm{~cm}$ wide, conduplicate at base. Racemes 1 or 2, arching, 8-30 cm long (usually $<15 \mathrm{~cm}$ long) from base of pseudobulb, many flowered; flowers green or greenish-white and resupinate; pedicels filiform, 2-6 (10) $\mathrm{mm}$ long, subtended by minute bracts; sepals subequal, linear-lanceolate, lip clawed and continuous with base of column, 3-5 mm long, 1-2 mm wide. Pseudobulbs completely covered by sheaths and lateral sepals free or connate $(1 / 2$ of their 
length) with recurved apices; it differs from N. orbicularis which presents pseudobulbs covered by sheaths only at the base and entirely connate lateral sepals.

Comments. Notylia barkeri is widely distributed in Mexico from Jalisco and Tamaulipas to southern Mexico, including Chiapas, Tabasco, and Quintana Roo (Tropicos 2017). In our survey, large populations (between five and 10 individuals per tree) were mainly observed in abandoned orange plantations. This species has not previously been recorded in semi-evergreen tropical forest. It is a twig epiphyte (Chase 1987) which grows in areas exposed to sunlight and tends to naturally occur at gaps or edges. The flowering period was from March to April in the study area.

Trichocentrum cosymbephorum (C. Morren) R. Jiménez \& Carnevali.

New record. Mexico: Hidalgo: municipality of San Felipe Orizatlán, Ahuatitla (2110'03.4” N, 098³9'59.7" W, $242 \mathrm{~m}$ elev.), in the abandoned orange (Citrus spp.) plantation "Camelia", coll. by A. Hernández-Orta, 12 November 2017, (Fig. 2C, D).

Identification. Trichocentrum cosymbephorum is an epiphyte, with leaves that generally exceed $12 \mathrm{~cm}$ long, oblong-elliptical to elliptical, acute; thin roots, $2 \mathrm{~mm}$ thick. Pseudobulbs very small, compressed and uniform, smooth, dark green. Inflorescences usually longer than leaves, more or less simultaneous, and with resupinate flowers (1-25), rarely successive flowers; lip without spur, with callous teeth of six proximal parts; distal teeth of calluses in two parts; central keel of the callus one or two times smaller than the length of the distal teeth of the callus. Morphologically similar to T. luridum, but characterized by its pale brown to pink flowers (not reddish-brown) and leaves, which are up to twice as long.

Comments. Trichocentrum cosymbephorum is endemic to Mexico, where it has a wide distribution. It is found at middle elevations from the Sierra Madre Oriental of Tamaulipas to Chiapas. It is scarce in the study area, with one to two individuals per tree. This species is an epiphyte, living mostly on abandoned orange trees or in backyard gardens. Some individuals grow in sunny sites along the edges of semi-evergreen tropical forest. Several individuals were rarely seen on the host trees Inga vera (Mimosaceae, Willd.) and Cedrela odorata (Meliaceae, L.). The flowering period was from October to November in the study area.

Espejo-Serna and López-Ferrari (1998) had previously reported the type (Mexico) of T. cosymbephorum in the state of Hidalgo under the name of Oncidium luridum Lindl. var. henchmannii Knowles \& Westc. However, the type was apparently lost or destroyed, so Christenson (1996) designated the lectotype, which enables us to confirm the presence of this species in Hidalgo.

\section{Discussion}

Notylia barkeri and Trichocentrum cosymbephorum are common species and widely distributed in Mexico, and therefore are not threatened according to SEMARNAT (2010). However, the new records are the first for

Table 1. Herbarium and GBIF records of Notylia barkeri Lindl. and Trichocentrum cosymbephorum (C. Morren) R. Jiménez \& Carnevali and the distances between each record and the new records (see Results).

\begin{tabular}{|c|c|c|c|c|c|c|c|}
\hline Species & Herbarium & Catalogue no. & State & Latitude & Longitude & Altitude (m) & Distance (km) \\
\hline N. barkeri & MEXU & 1162339 & Campeche & $18^{\circ} 24^{\prime} 33.0^{\prime \prime} \mathrm{N}$ & $089^{\circ} 29^{\prime} 34.0^{\prime \prime} \mathrm{W}$ & 295 & 1,006 \\
\hline N. barkeri & UCAM & 172 & Campeche & $20^{\circ} 10^{\prime} 21.0^{\prime \prime} \mathrm{N}$ & $090^{\circ} 23^{\prime} 40.0^{\prime \prime} \mathrm{W}$ & 9 & 868 \\
\hline N. barkeri & ECO-TA-H & 3732 & Chiapas & $15^{\circ} 01^{\prime} 10^{\prime \prime} \mathrm{N}$ & $092^{\circ} 06^{\prime} 20^{\prime \prime} \mathrm{W}$ & 850 & 973 \\
\hline N. barkeri & ZEA & 8835 & Jalisco & $19^{\circ} 38^{\prime} 13.0^{\prime \prime} \mathrm{N}$ & $104^{\circ} 23^{\prime} 42.0^{\prime \prime} \mathrm{W}$ & 225 & 623 \\
\hline N. barkeri & MO & 16126 & Michoacán & $18^{\circ} 35^{\prime} 00^{\prime \prime} \mathrm{N}$ & $103^{\circ} 31^{\prime} 00^{\prime \prime} \mathrm{W}$ & 178 & 582 \\
\hline N. barkeri & CNS-UT & 111443 & Nayarit & $21^{\circ} 11^{\prime} 10.3^{\prime \prime} \mathrm{N}$ & $105^{\circ} 07^{\prime} 26.6^{\prime \prime} \mathrm{W}$ & 30 & 670 \\
\hline N. barkeri & UAMIZ & 61316 & Oaxaca & $17^{\circ} 11^{\prime} 13^{\prime \prime} \mathrm{N}$ & $095^{\circ} 17^{\prime} 08^{\prime \prime} \mathrm{W}$ & 155 & 568 \\
\hline N. barkeri & UAMIZ & 31463 & Puebla & $20^{\circ} 05^{\prime} 36^{\prime \prime} \mathrm{N}$ & $097^{\circ} 37^{\prime} 30.5^{\prime \prime} \mathrm{W}$ & 505 & 160 \\
\hline N. barkeri & MEXU & 1181058 & Quinta Roo & $19^{\circ} 17^{\prime} 51.0^{\prime \prime} \mathrm{N}$ & $088^{\circ} 41^{\prime} 05.0^{\prime \prime} \mathrm{W}$ & 55 & 1,056 \\
\hline N.barkeri & $\mathrm{CICY}$ & 51784 & Quinta Roo & $19^{\circ} 46^{\prime} 13.9^{\prime \prime} \mathrm{N}$ & $087^{\circ} 44^{\prime} 23.3^{\prime \prime} \mathrm{W}$ & 9 & 1,150 \\
\hline N. barkeri & CNS-UT & 111441 & San Luis Potosí & $21^{\circ} 31^{\prime} 15.0^{\prime \prime} \mathrm{N}$ & $099^{\circ} 03^{\prime} 10.0^{\prime \prime} \mathrm{W}$ & 571 & 55 \\
\hline N. barkeri & UAMIZ & 9500 & Tabasco & $17^{\circ} 28^{\prime} 22^{\prime \prime} \mathrm{N}$ & $092^{\circ} 48^{\prime} 50^{\prime \prime} \mathrm{W}$ & 50 & 739 \\
\hline N. barkeri & UAMIZ & 44348 & Veracruz & $19^{\circ} 52^{\prime} 25.0^{\prime \prime} \mathrm{N}$ & $096^{\circ} 45^{\prime} 55.0^{\prime \prime} \mathrm{W}$ & 329 & 255 \\
\hline N. barkeri & XAL & 65354 & Veracruz & $20^{\circ} 46^{\prime} 00.0^{\prime \prime} \mathrm{N}$ & $098^{\circ} 16^{\prime} 30.0^{\prime \prime} \mathrm{W}$ & 225 & 60 \\
\hline N. barkeri & MEXU. & V007805 & Veracruz & $18^{\circ} 35^{\prime} 11^{\prime \prime} \mathrm{N}$ & $095^{\circ} 03^{\prime} 09^{\prime \prime} \mathrm{W}$ & 10 & 474 \\
\hline T. cosymbephorum & $\mathrm{CHIP}$ & 1824596 & Chiapas & $6^{\circ} 37^{\prime} 30.0^{\prime \prime} \mathrm{N}$ & $092^{\circ} 43^{\prime} 30.0^{\prime \prime} \mathrm{W}$ & 797 & 802 \\
\hline T. cosymbephorum & CHAPA & 79365 & Oaxaca & $16^{\circ} 44^{\prime} 30.0^{\prime \prime} \mathrm{N}$ & $094^{\circ} 10^{\prime} 30.0^{\prime \prime} \mathrm{W}$ & 1426 & 678 \\
\hline T. cosymbephorum & IEB & 931942 & Querétaro & $21^{\circ} 13^{\prime} 18.0^{\prime \prime} \mathrm{N}$ & $099^{\circ} 28^{\prime} 24.0^{\prime \prime} \mathrm{W}$ & 740 & 80 \\
\hline T. cosymbephorum & AMO & 95357 & Querétaro & $21^{\circ} 12^{\prime} 30.0^{\prime \prime} \mathrm{N}$ & $099^{\circ} 02^{\prime} 30.0^{\prime \prime} \mathrm{W}$ & 210 & 38 \\
\hline T. cosymbephorum & AMES & 2072000 & San Luis Potosí & $22^{\circ} 06^{\prime} 60.0^{\prime \prime} \mathrm{N}$ & $099^{\circ} 09^{\prime} 60.0^{\prime \prime} \mathrm{W}$ & 700 & 120 \\
\hline T. cosymbephorum & MO & 600737 & San Luis Potosí & $22^{\circ} 06^{\prime} 60.0^{\prime \prime} \mathrm{N}$ & $099^{\circ} 09^{\prime} 60.0^{\prime \prime} \mathrm{W}$ & 225 & 118 \\
\hline T. cosymbephorum & UJAT & 163666 & Tabasco & $17^{\circ} 57^{\prime} 10.0^{\prime \prime} \mathrm{N}$ & $092^{\circ} 32^{\prime} 53.0^{\prime \prime} \mathrm{W}$ & 1 & 736 \\
\hline T. cosymbephorum & $X A L$ & 163012 & Veracruz & $19^{\circ} 32^{\prime} 53.0^{\prime \prime} \mathrm{N}$ & $096^{\circ} 42^{\prime} 33.0^{\prime \prime} \mathrm{W}$ & 502 & 272 \\
\hline T. cosymbephorum & $X A L$ & 19726 & Veracruz & $18^{\circ} 26^{\prime} 48.0^{\prime \prime} \mathrm{N}$ & $095^{\circ} 01^{\prime} 34.0^{\prime \prime} \mathrm{W}$ & 520 & 486 \\
\hline
\end{tabular}


the state of Hidalgo. This state has a scarcity of orchid records despite the presence of semi-evergreen tropical forest remnants across $4.8 \%$ of its territory (Anonymous 1992). Semi-evergreen tropical forest is now only found in patches because it has largely been substituted by agricultural crops (Bertolini et al. 2012), including coffee and orange plantations. Notably, we expected to find orchid records in semi-evergreen tropical forest remnants but were taken to abandoned orange plantations by our guides. Orange plantations could be providing a new niche for these species.

The distances between the new records of $N$. barkeri and T. cosymbephorum and previous records are shown in Table 1. Finally, the geographical coordinates and elevation of the orchid records obtained from Herbarium and GBIF are shown in Table 1. In general, $N$. barkeri and T. cosymbephorum are distributed in lowlands (average elevation $=241.25 \mathrm{~m}$ and $591.36 \mathrm{~m}$, respectively) of the Atlantic slope (Table 1, Fig. 1).

Around $60 \%$ of the native vegetation of the state of Hidalgo has been transformed to crop fields, pastures, or human settlements (Martínez-Morales et al. 2007), so it is important to continue to explore this state's biodiversity in order understand it and promote its conservation. Additional exhaustive botanical surveys in the Huasteca region of Hidalgo and the remaining conserved forest fragments are needed to generate more accurate and upto-date knowledge of the orchid flora of the state, where few historical orchid records exist. However, as shown by our new records, abandoned crop plantations should also be surveyed. Additional surveys will generate valuable information needed to conserve the few remnants of native tropical forest. Finally, with the addition of $N$. barkeri and T. cosymbephorum in Hidalgo, the number of orchid species in the state is updated to 110, which represents around $9 \%$ of the orchid species recorded for Mexico (Ponce-Vargas et al. 2006; Ceja-Romero et al. 2010; Bertolini et al. 2012; Molina-Mendoza et al. 2012; Bertolini et al. 2016).

\section{Acknowledgements}

We are grateful to Oswaldo Enciso and his help with the identifications, Abril Sánchez Popoca for her comments that helped us improve the manuscript, Gabriel Flores Franco for providing access to the facilities of the HUMO Herbarium, and Allison Jermain for her revision of our English. Igor Soares dos Santos and an anonymous reviewer considerably improved the manuscript. Finally, we thank Ricardo Alejandro Garza Paredes for being a great colleague and friend who assisted us with the logistics of the survey and provided additional motivation for carrying out this project.

\section{Authors' Contributions}

CAHO made the collections and reviewed herbarium specimens; CAHO and JML made the identification;
CAHO and KMAD designed the study and wrote the manuscript. All of the authors contributed to the discussion, review, and approval of the final manuscript.

\section{References}

Anonymous (1992) Síntesis geográfica del estado de Hidalgo. Instituto Nacional de Estadística, Geografía e Informática. Aguascalientes, México, 134 pp.

Bertolini V, Damon A, Francisco Ramiro LT, Rojas-Velázquez AN (2012) Las orquídeas del Valle del Mezquital, Hidalgo México, resultados preliminares. Revista Chapingo Serie Zonas Áridas 11 (2): 85-94.

Bertolini V, Archila-Morales F (2016) Ponthieva nicolasii (Orchidaceae), una nueva especie para Hidalgo, México. Gayana Botanica 73: 462- 466. https://doi.org/10.4067/S0717-66432016000200462

Ceja-Romero J, Mendoza-Ruiz A, López-Ferrari AR, Espejo-Serna A, Pérez-García B, García-Cruz J (2010) Las epífitas vasculares del estado de Hidalgo, México: diversidad y distribución. Acta Botánica Mexicana 93: 1-39.

Cetzal-Ix W, Carnevali G, Romero-González G (2016) Synopsis of the Trichocentrum-clade (Orchidaceae, Oncidiinae). Harvard Papers in Botany 21 (2): 141- 169. https://doi.org/10.3100/hpib. v21iss2.2016.n3

Challenger A (1998) Utilización y Conservación de los Ecosistemas Terrestres de México; Pasado, Presente y Futuro. Comisión Nacional para el Conocimiento y Uso de la Biodiversidad. México, DF, México, 847 pp.

Chase MW (1987) Obligate twig epiphytism in the Oncidiinae and other neotropical orchids. Selbyana 10 (1): 24-30.

Christenson EA (1996) Notes on neotropical Orchidaceae II. Lindleyana 11 (1): 12-26.

Espejo-Serna A, López-Ferrari AR (1998) Las monocotiledóneas mexicanas: una sinopsis florística. 1. Lista de referencia. Parte VIII. Orchidaceae 2 Consejo Nacional de la Flora de México A.C., Universidad Autónoma Metropolitana Iztapalapa, Comisión Nacional para el Conocimiento y Uso de la Biodiversidad, México, 115 pp.

Givnish TJ, Spalink D, Ames M, Lyon SP, Hunter SJ, Zuluaga A, Doucette A, Caro GG, McDaniel J, Clements MA, Arroyo MTK, Endara L, Kriebel R, Williams NH, Cameron KM (2016) Orchid historical biogeography, diversification, Antarctica and the paradox of orchid dispersal. Journal of Biogeography 43 (10): 1905-1916. https://doi.org/10.1111/jbi.12854

Hágsater E, Soto-Arenas MÁ, Salazar GA, Jiménez-Machorro R, López Rosas MA, Dressler RL (2005) Las orquídeas de México. Instituto Chinoín, México, DF, 304 pp.

Lot A, Chiang F (1986) Manual de herbario, administración y manejo de colecciones técnicas de recolección y preparación de ejemplares botánicos. Consejo Nacional de la Flora de México, DF, México, 142 pp.

Luna J (1997) Monografía de la huasteca hidalguense, Pachuca, Hidalgo, México. Serie Cuadernos Hidalguenses 11. Consejo Estatal para la Cultura y las Artes de Hidalgo, Pachuca, 88 pp.

Martínez-Morales MA, Ortiz-Pulido R, De la Barreda B, Zuria IL, Bravo-Cadena J, Valencia-Hervert J (2007) Hidalgo. In: OrtizPulido R, Navarro-Sigüenza A, Gómez de Silva H, Rojas-Soto O, Peterson TA (Eds) Avifaunas estatales de México. Sociedad para el Estudio y la Conservación de las Aves en México, Pachuca, Mexico, 49-95 pp.

Molina-Mendoza JL, Galván-Villanueva R, Patiño-Siciliano A, Fernández-Nava R (2012) Plantas medicinales y listado florístico preliminar del municipio de Huasca de Ocampo, Hidalgo, México. Polibotánica 34: 259-291.

Ponce-Vargas A, Luna-Vega I, Alcántara-Ayala O, Ruiz-Jiménez CA (2006) Florística del bosque mesófilo de montaña de Monte Grande, Lolotla, Hidalgo, México. Revista Mexicana de Biodi- 
versidad 77 (2): 177-90.

SEMARNAT (Secretaría de Medio Ambiente y Recursos Naturales) (2010) Norma oficial Mexicana NOM-059-SEMARNAT-2010, protección ambiental-especies nativas de México de flora y fauna silvestres-categorías de riesgo y especificaciones para su inclusión, exclusión o cambio-lista de especies en riesgo. Diario Oficial de la Federación. 30 de diciembre de 2010. Segunda Sección. México.

Soto-Arenas MÁ (1996) Mexico (regional account). In: IUCN/SSC, Orchid Specialist Group (Ed.) Orchids, status survey and conser- vation action plan. IUCN, Gland, 53-58 pp.

Soto-Arenas MÁ, Hágsater E, Jiménez R, Salazar GA, Solano-Gómez R, Flores R (2007) Las orquídeas de México. Catálogo digital (CD-ROM, Windows-Mac). Instituto Chinoín, México, DF.

The Plant List (2018) https://www.theplantlist.org. Accessed on: 201812-18.

Villavicencio-Nieto MÁ, Pérez-Escandón BE, Ramírez-Aguirre A (1998) Lista florística del estado de Hidalgo, recopilación bibliográfica. Universidad Autónoma del Estado de Hidalgo. Centro de Investigaciones Biológicas, Pachuca, México, 147 pp. 